\title{
伸展する宇宙構造物のゲインスケジューリング制御*
}

\author{
李光 焔*1, 長塩知 之年, 木田 隆*2
}

\section{Gain-Scheduling Control for Extending Space Structures}

Kouen $\mathrm{LI}^{* 3}$ and Tomoyuki NAGASIO and Takashi KIDA

\author{
${ }^{* 3}$ University of Electro-Communications, \\ 1-5-1 Chofugaoka, Chofu-shi, Tokyo, 182-8585 Japan
}

\begin{abstract}
This paper studies a control of the extending space structures in orbit under gravity-gradient environment. To this end, it first introduces an equation of motion of the satellite that extends on the orbit and shows that it is a linear time-varying system. Then it is represented as a linear parameter varying system and gain-scheduling control method is applied to control it. In order to design the non-conservative controller, the analytical method of constructing the smallest number of scheduling parameters is proposed based on a typical cylinder model. Finally, even when the generalized plant has the model error, it is shown to be applicable by adding the robust property with the constant matrix scaling. The availability of the proposed methods is proved through numerical simulations.
\end{abstract}

Key Words: Gain-Scheduling, Liner Parameter Varying System, Extending Space Structures

\section{1. 緒 言}

近年の宇宙開発は目的が多様化, 高度化してきてお り, その要求を満たすため宇宙構造物は大型化してき ている.このような大型宇宙構造物は宇宙ステーショ ンのように低軌道上に建設されるものが多いが，ロケッ トで一度に運搬できる重量および容量に制約があるた め, 実際に運用される軌道上で複数のモジュールを組 み立て, 伸展させることが必要となる. この時, 伸展中 であっても構造物の姿勢運動は安定であることが望ま れる. 低軌道上では重力傾度トルクが支配的な外乱卜 ルクとなる. この重力傾度トルクは伸展しない衛星で は各軸の慣性モーメントが特定の条件を満たせば, 姿 勢運動を安定化するトルクとして作用する特徵を持つ ことが知られており,そのための安定性の条件が求め られている ${ }^{(1)}$. しかし, 衛星が伸展する場合は伸展し ない場合とは運動方程式が異なり時変システムとなる ため, このような重力傾度安定化は実現できない. そ のため伸展が姿勢運動に及ぼす影響を考虑し, 伸展中 での姿勢運動の安定性を保証することが必要である. また安定化だけでなく, 十分な外乱抑制性能を持つ制 御系を設計することが重要である.

* 原稿受付 2003 年 6 月 18 日

*1 電気通信大学大学院電気通信学研究科機械制御工学専攻( 182-8585 調布市調布ヶ丘 1-5-1).

*2 正員, 電気通信大学知能機械工学科.

E-mail : lgy@ctr.mce.uec.ac.jp
これまでにも時変システムに関する安定性について は多くの研究がなされている. しかし, 既存の安定定 理は保守的で伸展衛星の制御系設計には適していない. このため, 時変係数を持つ線形 2 階行列微分方程式に 関する安定定理をリアプノフ関数を用いて導出し, 伸 展衛星の問題に適用し漸近安定性を保証する研究も行 われている ${ }^{(2)}$. しかし，この方法は安定性は保証でき るが, より高い制御性能を達成するには限界があるで あろうし,そのための系統的な設計法はない. そこで, 本論文ではゲインスケジューリング制御理論を用いて, 伸展衛星の制御問題に適用する.これは, 伸展衛星の 長さと伸展速度をオンラインで計測し, それらの值を 用いた可変な制御器を設計することにより, システム の安定性と制御性能を保証する方法である. この制御 法を用いて保守性を低減させるには, スケジューリン グパラメータの設定の方法が重要になる. しかしなが ら, 伸展衛星のモデルでは, その長さと伸展速度の乗 除算によって慣性モーメントなどの物理パラメータが 決まるために, それらの值を直接的に独立した設計パ ラメータとすることが難しく, スケジューリングパラ メータの個数が膨大なものとなる.このため, 保守性 を低減させることは容易ではない, そこで, 本稿では, モデルの運動方程式を具体的に解析することによって， 長さと伸展速度からなる関数を新たに構筑し, それを 
スケジューリングパラメータとすることで, この問題 の回避をはかることにする.さらに, 本稿では, 観測さ れる伸展衛星の長さと伸展速度に誤差が存在する場合 においても, システムのロバスト安定性とロバスト性 能が保証できるように，このゲインスケジューリング 制御に, $H_{\infty}$ 定数スケーリング制御を合わせて用いる ことを検討する. そして, これらの制御法の有効性を 検証するために, 円柱モデルを用いた数值シミュレー ションを行う.

\section{2. 伸展する剛体衛星のモデル}

\section{$2 \cdot 1$ 座標系}

ここでは剛体の衛星が円軌道上を運動する場合を考 える. まず地球に固定した慣性座標系 $\{e\}$ を定義する. そして軌道座標系 $\{o\}$ を, 衛星の質量中心から地球中 心方向を $o_{3}$ 軸, 軌道面法線方向を $o_{2}$ 軸, 軌道の接線 方向を $o_{1}$ 軸とする. また衛星の姿勢を表す機体座標 系 $\{b\}$ は，この軌道座標系から 3-2-1 系のオイラー角 を用いて, 3 軸回りに $\phi_{3}, 2$ 軸回りに $\phi_{2}, 1$ 軸回りに $\phi_{1}$ 回転して得られるものとする. 衛星の姿勢は, ロー ル角 $\phi_{1}$ ，ピッチ角 $\phi_{2}$, ヨー角 $\phi_{3}$ で表現される. こう して得られる機体座標系 $\{b\}$ のうち, $b_{1}$ 軸をロール軸 (進行方向), $b_{2}$ 軸をピッチ軸 (軌道面法線方向), そし て $b_{3}$ 軸をヨ一軸 (地球中心方向) とする.

\section{$2 \cdot 2$ 運動方程式}

上述した機体座標系 $\{b\}$ で表すと, 重力傾度トルク を考慮した伸展衛星の姿勢運動はダイナミクス方程式

$$
J \dot{\omega}+\dot{J} \omega+\omega \times J \omega=T^{c}+T^{G}
$$

とキネマティクス方程式

$$
\dot{\phi}=\pi^{-1}(\phi) \omega
$$

で表現できる ${ }^{(3)}$.ここで $J \in R^{3 \times 3}$ は慣性モーメン 卜行列, $\omega \in R^{3}$ は角速度ベクトル, $\phi=\left[\phi_{1}, \phi_{2}, \phi_{3}\right]^{T}$ はオイラー角を用いた姿勢角度ベクトルである. また $T^{c} \in R^{3}$ は外部からの入力ベクトル, $T^{G} \in R^{3}$ は重力 傾度トルクを表すべクトルであり

$$
T^{G}=-\frac{3 \mu}{R^{3}}\left[\begin{array}{ccc}
\left(J_{2}-J_{3}\right) & 0 & 0 \\
0 & \left(J_{1}-J_{3}\right) & 0 \\
0 & 0 & 0
\end{array}\right]\left[\begin{array}{l}
\phi_{1} \\
\phi_{2} \\
\phi_{3}
\end{array}\right]
$$

で与えられる. 式 (3) において, $\mu$ は引力定数, $R$ は地 球中心から衛星の質量中心までの距離である. 式 (2) において, $\pi$ は衛星の姿勢角度 $\phi$ と角速度 $\omega$ の関係を 表す $\phi$ の関数である ${ }^{(3)}$. 宇宙構造物の姿勢安定化は 平衡点近傍で扱うので, その角度および角速度が微小
と考えて

$$
\begin{aligned}
& \dot{\phi} \approx \omega \\
& \omega \times J \omega \approx 0
\end{aligned}
$$

と近似すると, 式 (1),(2) および (3) は

$$
M(J) \ddot{\phi}+D(\dot{J}) \dot{\phi}+K(J) \phi=T^{c}
$$

となる.ここで

$$
\begin{aligned}
M & =\operatorname{diag}\left\{J_{1}, \quad J_{2}, \quad J_{3}\right\} \\
D & =\operatorname{diag}\left\{\dot{J}_{1}, \dot{J}_{2}, \dot{J}_{3}\right\} \\
K & =\frac{3 \mu}{R^{3}} \operatorname{diag}\left\{\left(J_{2}-J_{3}\right), \quad\left(J_{1}-J_{3}\right), 0\right\}
\end{aligned}
$$

であり, 慣性モーメントの時間微分項を含む線形時変 システムとなる.

\section{$2 \cdot 3$ 円柱モデルの惯性モーメント}

以上に示した運動方程式に対して,ここでは簡単の ために伸展衛星モデルとして図 1 のような用体円柱を 考える.

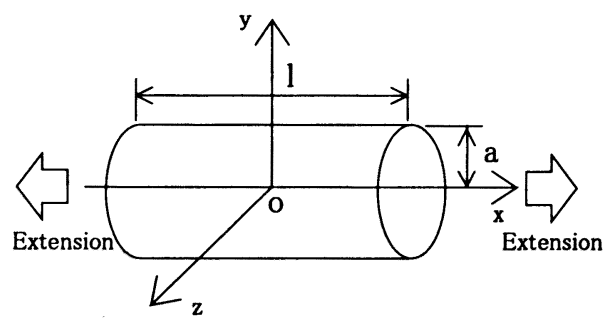

Fig 1 Cylinder Model

そして円柱は質量一定のままで質量中心 oに対して $x$ 軸方向に対称に伸展するものと仮定する. 物理的な パラメータをそれぞれ, 質量 : $m$, 円柱半径 : $a$, 円柱 の初期長さ $: l_{0}$, 伸展速度 $: l_{v}$ とすると, 円柱の軸に関 する慣性モーメント $J_{x}$ と直交する 2 つの軸に関する 慣性モーメント $J_{y}, J_{z}$ は

$$
\begin{array}{ll}
J_{x}=\frac{1}{2} m a^{2}, & J_{y}=J_{z}=\frac{1}{4} m\left(a^{2}+\frac{1}{3} l^{2}\right) \\
\dot{J}_{x}=0, & \dot{J}_{y}=\dot{J}_{z}=\frac{1}{6} m l l_{v}
\end{array}
$$

となる. そのため, $J_{x}$ は定数となるが, $J_{y}, J_{z}$ は $l$ と $l_{v}$ が時間と共に変化するため時変となる.

伸展しない衛星の姿勢運動は重力傾度トルクの影響 で, 各軸の慣性モーメントが先述した座標系において $J_{2} \geq J_{1}>J_{3}$ となれば安定であることがよく知られ ている ${ }^{(1)}$. しかし伸展衛星の運動方程式は時変系とな るため, この重力傾度安定条件は適用できない. 
3. 伸展街星のゲインスケジューリング制御

\section{$3 \cdot 1$ ゲインスケジューリング制御}

以上に述べたように, 伸展衛星の運動方程式は時変 系となっている. 従来, 時変のパラメータ変動を持つ システムの制御の一つとして $H_{\infty}$ 制御設計法などが 使われてきた．これは時変パラメータの影響を，有界 なモデル誤差として表現し，ノミナルモデルに対する ロバスト安定性を保証する時不変の制御則を設計する 方法である ${ }^{(4)}$. しかし, モデル誤差の変動が大きい場 合にはロバスト安定性を保証することが困難になるこ とが予想され，また，たとえ設計できたとしても時不 変の制御器では, 性能に対する保守性を低減すること が難しい. そこでここでは, このような問題に対して， ゲインスケジューリング制御設計法 ${ }^{(5)}$ を適用する.

この設計法は LPV(Linear Parameter Varying) モ デルとなる制御対象を,アフィンパラメータベクトル $p(t)=\left[p_{1} \cdots p_{n}\right]^{T}$ に依存する一般化プラント

$$
P(p):\left\{\begin{array}{l}
\dot{x}=A(p) x+B_{1}(p) w+B_{2} u \\
z=C_{1}(p) x+D_{11}(p) w+D_{12} u \\
y=C_{2} x+D_{21} w+D_{22} u
\end{array}\right.
$$

として表現し

$$
p(t)=\sum_{i=1}^{n} \alpha_{i} \Pi_{i}, \quad \alpha_{i} \geq 0, \quad \sum_{i=1}^{n} \alpha_{i}=1
$$

となる関係を用いた凸分解

$$
P(p)=\sum_{i=1}^{n} \alpha_{i} P\left(\Pi_{i}\right)
$$

の各端点における LTI(Linear Time Invariant) プラン 卜 $P\left(\Pi_{i}\right)$ に対して, $H_{\infty}$ 制御理論における有界実補題 を用いて LTI 制御器 $K\left(\Pi_{i}\right)$ を設計し，これを凸結合す ることによって, パラメータ $p(t)$ 依存となる LPV 制 御器

$$
K(p):\left\{\begin{array}{l}
\dot{x}_{k}=A_{k}(p) x_{k}+B_{k}(p) y \\
u=C_{k}(p) x_{k}+D_{k}(p) y
\end{array}\right.
$$

を設計する手法である.この設計法では, LPV モデ ルのパラメータ変動をモデル誤差として扱うのではな く, 直接的にスケジューリングパラメータとして用い る. そのため, パラメータベクトルに, 時変となる動特 性を持つ值を設定することが可能であり，その変化が 有界な範囲に収まる場合には, 優れた能力を持つ LPV 制御器の実現が期待できる.

\section{$3 \cdot 2$ 制御系設計}

ゲインスケジューリング制御系を設計するために,
制御入力を $u$, 外乱を $w$ として, $T^{c}=u+w$ とおけば, 式 (5) は

$$
M(J) \ddot{\phi}+D(\dot{J}) \dot{\phi}+K(J) \phi=u+w
$$

となる.このモデルに対し，ここでは図 2 に示すよう な一般化プラントを考える.ここで観測量 $y$ は姿勢角 度であり, 制御量 $z_{1}$ は観測量を，また $z_{2}$ は制御入力 をそれぞれ評価し，外乱抑制性能の向上と制御入力の 低減を図ることにする。

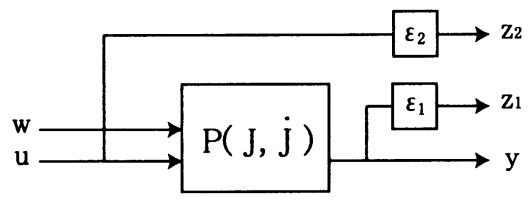

Fig 2 Block Diagram

この時, パラメータ依存となる一般化プラントは

$$
\begin{aligned}
\dot{x} & =\left[\begin{array}{cc}
0 & I \\
-M^{-1} K-M^{-1} D
\end{array}\right] x+\left[\begin{array}{c}
0 \\
M^{-1}
\end{array}\right] w+\left[\begin{array}{c}
0 \\
M^{-1}
\end{array}\right] u \\
& =A(J, \dot{J}) x+B_{1}(J, \dot{J}) w+B_{2}(J, \dot{J}) u \\
z & =\left[\begin{array}{c}
z_{1} \\
z_{2}
\end{array}\right]=\left[\begin{array}{cc}
\varepsilon_{1} I & 0 \\
0 & 0
\end{array}\right] x+\left[\begin{array}{c}
0 \\
\varepsilon_{2} I
\end{array}\right] u \\
& =C_{1} x+D_{12} u \\
y & =\left[\begin{array}{ll}
I & 0
\end{array}\right] x \\
& =C_{2} x
\end{aligned}
$$

となる.ただし

$$
x=\left[\begin{array}{ll}
\phi^{T} & \dot{\phi}^{T}
\end{array}\right]^{T}
$$

である。

この一般化プラントに対し, 設計する制御器 $K(J, \dot{J})$ は次のような条件を満足しなければならない。

・閉ループ系は全ての許容されるパラメータ軌道 $J(t), \dot{J}(t)$ に対して安定である.

- 外乱 $w$ から制御量 $z$ までの閉ループゲインはあ る正の值 $\gamma$ を超えない $\left(\left\|G_{z w}(J, \dot{J})\right\|_{\infty} \leq \gamma\right)$.

この設計問題は，一般的に LMI(Linear Matrix Inequality: 線形行列不等式) に帰着できることが知 られている ${ }^{(5)}$. しかし, 式 (13) においては, $B_{2}$ 行列 が時変パラメータに依存するため, LMI 可解条件が満 たされない(5),(6).そこで,ここでは式(15)のような ローパスフィルタを制御入力端に加えることを考える.

$$
\begin{aligned}
& \dot{\zeta}=A_{\zeta} \zeta+B_{\zeta} \tau \\
& u=C_{\zeta} \zeta
\end{aligned}
$$


また伸展中で予測できない地磁気, 太陽輻射圧などの 低周波数成分を持つ宇宙環境外乱が考えられ，これを 抑制し, 制御性能を向上させるために, 式 (16)のよう なローパスフィルタを加えることにする.

$$
\begin{aligned}
& \dot{\rho}=A_{\rho} \rho+B_{\rho} w \\
& d=C_{\rho} \rho
\end{aligned}
$$

これにより, 拡張された一般化プラントは式 (17) で表 される.

$$
\begin{aligned}
\dot{x} & =\left[\begin{array}{ccc}
A & B_{1} C_{\zeta} & B_{1} C_{\rho} \\
0 & A_{\zeta} & 0 \\
0 & 0 & A_{\rho}
\end{array}\right] x+\left[\begin{array}{c}
0 \\
0 \\
B_{\rho}
\end{array}\right] w+\left[\begin{array}{c}
0 \\
B_{\zeta} \\
0
\end{array}\right] \tau \\
& =A_{e}(J, \dot{J}) x+B_{1 e} w+B_{2 e} \tau \\
z & =\left[\begin{array}{ccc}
C_{1} & 0 & 0 \\
0 & C_{\zeta} & 0
\end{array}\right] x \\
& =C_{1 e} x \\
y & =\left[\begin{array}{lll}
C_{2} & 0 & 0
\end{array}\right] x \\
& =C_{2 e} x \\
こ こ て ゙ & \quad x=\left[\begin{array}{llll}
\phi^{T} & \dot{\phi}^{T} & \zeta^{T} & \rho^{T}
\end{array}\right]^{T}
\end{aligned}
$$

である、

この一般化プラントに対して, ゲインスケジューリ ング制御器を設計するためには, 式 (17) の一般化プラ ントをパラメータベクトル $p(t)$ に依存するアフィン関 数として表現する必要があるが, 式 (17) は慣性モ一メ ント $J$ とその時間微分 $\dot{J}$ に依存し, その值をオンライ ンで測定することは難しい.しかしながら, 慣性モー メントは構造物の質量, 寸法等で表現できるため, 衛 星の伸展長さ $l$ と伸展速度 $l_{v}$ が測定できれば, $J$ と $j$ が算出できる. そのため, 伸展長さ $l$ と伸展速度 $l_{v}$ を それぞれ独立したスケジューリングパラメータに設定 すれば, $J$ と $j$ をパラメータとする場合に比べ, より 直接的なパラメータ変動を扱うことができ, 実用的で ある. しかし, 本稿のモデルでは, 式 (7) からわかるよ うに, $l$ と $l_{v}$ をアフィン関数の独立したスケジューリ ングパラメータに設定することができない，そこで， ここではパラメータ $p$ を以下のような $l$ と $l_{v}$ の関数に することを考える.

$$
\begin{aligned}
p & =\left[\begin{array}{llll}
p_{1} & p_{2} & \cdots & p_{n}
\end{array}\right] \\
& =\left[\begin{array}{llll}
f_{1}\left(l, l_{v}\right) & f_{2}\left(l, l_{v}\right) & \cdots & f_{n}\left(l, l_{v}\right)
\end{array}\right]
\end{aligned}
$$

これにより，ある動作点の測定值 $l$ と $l_{v}$ がわかれば, その時の構造化されたパラメータ $p$ を算出することが
できる.したがって, 式 $(17) の A_{e}(J, \dot{J})$ 行列は

$$
A_{e}(p)=A_{0}+p_{1} A_{1}+p_{2} A_{2}+\cdots+p_{n} A_{n}
$$

となり,構造化されたパラメータ $p$ のアフィン関数で 表現できる. 円柱モデルを用いた衛星が $b_{1}$ 軸に伸展 する場合について, この関倸を考える. この時 $b_{1}$ 軸は 図 1 の $x$ 軸と一致するので

$$
\begin{array}{ll}
J_{1}=\frac{1}{2} m a^{2} & \dot{J}_{1}=0 \\
J_{2}=J_{3}=\frac{1}{4} m\left(a^{2}+\frac{1}{3} l^{2}\right) & \dot{J}_{2}=\dot{J}_{3}=\frac{1}{6} m l l_{v}
\end{array}
$$

となる.したがって, 行列 $A_{e}(p)$ は

$$
A_{e}(p)=\left[\begin{array}{lccr}
0 & I & 0 & 0 \\
\hat{A}_{1} & \hat{A}_{2} & \hat{A}_{3} & \hat{A}_{4} \\
0 & 0 & A_{\zeta} & 0 \\
0 & 0 & 0 & A_{\rho}
\end{array}\right]
$$

となる.ここで

$$
\begin{aligned}
& \hat{A}_{1}=\operatorname{diag}\left\{0,-\frac{3 \mu}{R^{3}} \cdot \frac{3 a^{2}-l^{2}}{3 a^{2}+l^{2}}, 0\right\} \\
& \hat{A}_{2}=\operatorname{diag}\left\{0, \frac{2 m l l_{v}}{3 a^{2}+l^{2}}, \frac{2 m l l_{v}}{3 a^{2}+l^{2}}\right\} \\
& \hat{A}_{3}=\operatorname{diag}\left\{\frac{2}{m a^{2}}, \frac{12}{m\left(3 a^{2}+l^{2}\right)}, \frac{12}{m\left(3 a^{2}+l^{2}\right)}\right\} C_{\zeta} \\
& \hat{A}_{4}=\operatorname{diag}\left\{\frac{2}{m a^{2}}, \frac{12}{m\left(3 a^{2}+l^{2}\right)}, \frac{12}{m\left(3 a^{2}+l^{2}\right)}\right\} C_{\rho}
\end{aligned}
$$

である.したがって

$$
\begin{aligned}
p & =\left[\begin{array}{ccc}
p_{1} & p_{2} & p_{3}
\end{array}\right] \\
& =\left[\begin{array}{lll}
\frac{1}{3 a^{2}+l^{2}} & \frac{l \cdot l_{v}}{3 a^{2}+l^{2}} & \frac{l^{2}}{3 a^{2}+l^{2}}
\end{array}\right]
\end{aligned}
$$

のように構造化すれば

$$
\begin{aligned}
A_{e}(p) & =\left[\begin{array}{cccc}
0 & I & 0 & 0 \\
0 & 0 & \tilde{A}_{01} & \tilde{A}_{02} \\
0 & 0 & A_{\zeta} & 0 \\
0 & 0 & 0 & A_{\rho}
\end{array}\right]+p_{1}\left[\begin{array}{cccc}
0 & 0 & 0 & 0 \\
\tilde{A}_{11} & 0 & \tilde{A}_{12} & \tilde{A}_{13} \\
0 & 0 & 0 & 0 \\
0 & 0 & 0 & 0
\end{array}\right] \\
& +p_{2}\left[\begin{array}{cccc}
0 & 0 & 0 & 0 \\
0 & \tilde{A}_{2} & 0 & 0 \\
0 & 0 & 0 & 0 \\
0 & 0 & 0 & 0
\end{array}\right]+p_{3}\left[\begin{array}{cccc}
0 & 0 & 0 & 0 \\
\tilde{A}_{3} & 0 & 0 & 0 \\
0 & 0 & 0 & 0 \\
0 & 0 & 0 & 0
\end{array}\right] \\
& =A_{0}+p_{1} A_{1}+p_{2} A_{2}+p_{3} A_{3}
\end{aligned}
$$

として, 行列 $A_{e}(p)$ は $p$ のアフィン関数で表現できる. 
ここで

$$
\begin{aligned}
& \tilde{A}_{01}=\operatorname{diag}\left\{\frac{2}{m a^{2}}, 0,0\right\} C_{\zeta} \\
& \tilde{A}_{02}=\operatorname{diag}\left\{\frac{2}{m a^{2}}, \quad 0, \quad 0\right\} C_{\rho} \\
& \tilde{A}_{11}=\operatorname{diag}\left\{0,-\frac{9 \mu a^{2}}{R^{3}}, \quad 0\right\} \\
& \tilde{A}_{12}=\operatorname{diag}\left\{0, \frac{12}{m}, \frac{12}{m}\right\} C_{\zeta} \\
& \tilde{A}_{13}=\operatorname{diag}\left\{0, \frac{12}{m}, \frac{12}{m}\right\} C_{\rho} \\
& \tilde{A}_{2}=\operatorname{diag}\{0,2 m, 2 m\} \\
& \tilde{A}_{3}=\operatorname{diag}\left\{0, \frac{3 \mu}{R^{3}}, 0\right\}
\end{aligned}
$$

\section{は定数行列である.}

以上の作業により得られた一般化プラント(図 3)に 対し, 各端点の制御器 $K\left(\Pi_{i}\right)$ を設計し, $l$ と $l_{v}$ をオン ラインで計測することによって, 閉ループ系の安定性 を保証するスムーズなスケジューリングが可能となる.

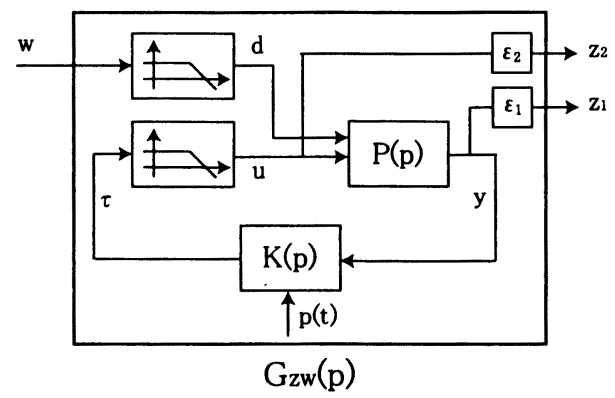

Fig 3 Control Block Diagram

\section{3 モデル誤差がある時のロバスト制御系設計}

以上に述べた設計法では, 観測される伸展長さ $l$ と 伸展速度 $l_{v}$ が全て正確であると考えてきた。 しかし ながら，実際には，そのスケジューリングパラメータ $l, l_{v}$ の測定值には誤差が存在する場合が考えられるた め, そのままでは, 閉ループ系のロバスト安定性を保 証するのに十分ではない. そこで次に, 定数スケーリ ング $H_{\infty}$ 制御設計法とこのグインスケジューリング 制御設計法を合わせて, パラメータ誤差に対してロバ スト安定性とロバスト性能の仕様を満たすゲインスケ ジューリング制御則を設計することを試みる.これに より, 観測誤差を一般化プラントのモデル誤差として 表現し，ロバスト安定性を保証することができる.

この設計法では, 式 (17) は

$$
\begin{aligned}
& \dot{x}=\left(A(p)+A_{\Delta}\right) x+B_{1 e} w+B_{2 e} \tau \\
& z=C_{1 e} x \\
& y=C_{2 e} x
\end{aligned}
$$

で表現される. $A(p)$ は観測された伸展長さ $l$ と伸展速 度 $l_{v}$ の值によって, 求められる各時刻のノミナル值で あり, $A_{\Delta}$ はその加法的モデル䛊差を表す.ここで, $\Delta l$ と $\Delta l_{v}$ をそれぞれ伸展長さ $l$ と伸展速度 $l_{v}$ の観測誤 差とおくと, $A_{\Delta}$ は

$$
A_{\Delta}=A\left(p\left(l+\Delta l, l_{v}+\Delta l_{v}\right)\right)-A\left(p\left(l, l_{v}\right)\right)
$$

と表現できる. そこでこれを

$$
A_{\Delta}=E_{A} \Delta_{A} F_{A}, \quad \Delta_{A}^{T} \Delta_{A} \leq I
$$

とおく.ここで, 行列 $E_{A}, F_{A}$ はモデル誤差を採動 $\Delta_{A}$ に正規化する倸数行列である. この攝動項の入出力関 係を

$$
w_{A}=\Delta_{A} z_{A}=\Delta_{A} F_{A} x
$$

と定義する, 次にロバスト性能を達成するために仮想 的なモデル誤差 $\Delta$ を導入して

$$
w=\Delta z=\Delta C_{1 e} x, \quad \Delta^{T} \Delta \leq I
$$

とすれば

$$
\Delta_{c}=\operatorname{diag}\left\{\Delta, \Delta_{A}\right\}, \quad \Delta_{c}^{T} \Delta_{c} \leq I
$$

となる構造化された㨟動項と，それに対する一般化プ ラント

$$
\begin{aligned}
\dot{x} & =A(p) x+\left[\begin{array}{ll}
B_{1 e} & E_{A}
\end{array}\right]\left[\begin{array}{l}
w \\
w_{A}
\end{array}\right]+B_{2 e} \tau \\
& =A(p) x+B_{1 c} w_{c}+B_{2 e} \tau \\
z_{c} & =\left[\begin{array}{c}
z \\
z_{A}
\end{array}\right]=\left[\begin{array}{l}
C_{1 e} \\
F_{A}
\end{array}\right] x \\
& =C_{1 c} x \\
y & =C_{2 e} x
\end{aligned}
$$

が得られる. この一般化プラントを伝達関数 $P_{c}(p)$ と 表現しておく.この時, 閉ループ系

$$
G_{c}(p)=F_{l}\left(P_{c}(p), K(p)\right)
$$

を内部安定にし, かつ, その $H_{\infty}$ ノルムを

$$
\left\|G_{c}(p)\right\|_{\infty}<1
$$

とするような制御器 $K(p)$ が設計できれば，この閉 ループ系は小ゲイン定理より $\Delta_{A}$ に対するロバスト 安定性と $\Delta$ に対するロバスト性能が保証される.こ こで， $F_{l}$ は線形分数変換 (LFT: Linear Fractional Transformation) を表す (7). しかし, 式 (32) のモデ 
ル誤差 $\Delta_{c}$ はブロック対角構造を持っているので, 式 (35) を満たす制御則 $K(p)$ は保守的となり, 制御性能 が劣るものとなる. そこで, ここでは, 摂動項 $\Delta_{c}$ と可 換な構造となる定数スケーリング行列 $S, S^{-1}$ を用い た閉ループ系 $S G_{c}(p) S^{-1}$ に対して

$$
\left\|S G_{c}(p) S^{-1}\right\|_{\infty}<1
$$

となるロバスト安定条件を満たすゲインスケジュー リング制御器を設計することにする.ここで述べて いるようにスケーリング行列 $S$ と $K(p)$ の最適化計 算は BMI(Bilinear Matrix Ineuqlity, 双線形行列不等 式) となるため, 容易に解を求めることができない，そ こで, $S$ を事前に決めて, 式 (36) を満たすゲインスケ ジューリング制御器 $K(p)$ を求める. そして, 求めら れた $K(p)$ を用いて, 式 $(36)$ を満たすスケーリング行 列 $S$ を求め, その繰り返し計算によって, 準最適な設 計を行うことにする.この反復法では, 準最適解しか 得られないが，より直接的に閉ループ系の $H_{\infty}$ ノルム を最適化する寒用的な設計法である. この時の制御系 を図 4 に示す.

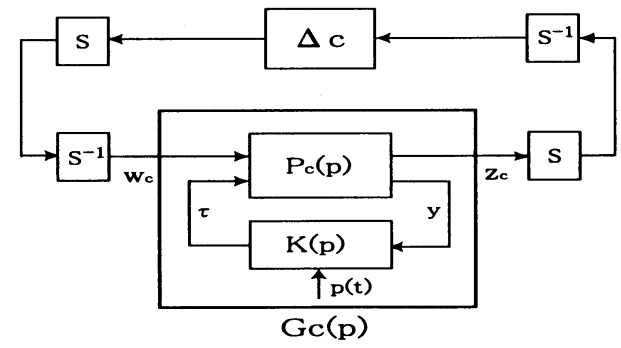

Fig 4 Control Block Diagram

\section{4. 数値シミュレーション}

\section{1 数值例 1}

ここでは, 3.2 節に述べた制御系設計法の有効性を 検証するために, $b_{1}$ 軸方向へ伸展させる場合のシミュ レーションを行う. 得られた制御系は $l, l_{v}$ を直接測定 してこれらをスケジューリングパラメータとしてゲイ ンスケジューリング制御を行うものである.したがっ て,この制御系設計法では任意の伸展速度に対する安 定性を保証することができる. そこで,ここでは伸展 速度を変化させ, 伸展を途中で停止させるような伸展 法を行わせてみることとし, 伸展長さ $l$ を

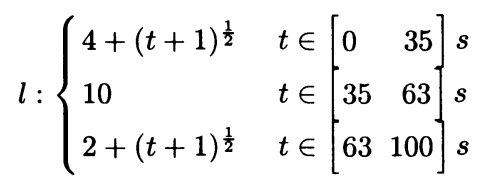

また, 伸展速度を

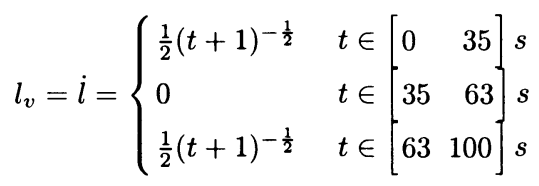

と設定する. 初期の長さは $5 \mathrm{~m}$, 伸展後の長さは $12.05 \mathrm{~m}$ となる. 定数パラメータをそれぞれ

$$
\begin{aligned}
& R=6778[\mathrm{~km}], m=700[\mathrm{~kg}], a=2.5[\mathrm{~m}], \\
& l_{0}=5[\mathrm{~m}], l_{v}=0.05[\mathrm{~m} / \mathrm{s}]
\end{aligned}
$$

と設定する.もし，本稿が用いた解析手法を適用しな い場合, 式(17)より, スケジューリングパラメータは $A_{e}(J, \dot{J})$ 行列の各要素を数值的に設定するため

$$
\begin{aligned}
& p=\left[\begin{array}{llllll}
J_{1}^{-1} J_{2} & J_{1}^{-1} J_{3} & J_{2}^{-1} J_{1} & J_{2}^{-1} J_{3} & J_{1}^{-1} \dot{J}_{1}
\end{array}\right. \\
& \left.\begin{array}{lllll}
J_{2}^{-1} \dot{J}_{2} & J_{3}^{-1} \dot{J}_{3} & J_{1}^{-1} & J_{2}^{-1} & J_{3}^{-1}
\end{array}\right]
\end{aligned}
$$

となり, 端点の数は $2^{10}=1024$ となる. 円柱モデル に限定した場合は $J_{1}$ が定数であるので, $p$ の第 5 要 素 $J_{1}^{-1} \dot{J}_{1}=0$, 第 8 要素 $J_{1}^{-1}=\mathrm{const}$ であるため, ス ケジューリングパラメータの数は 8 となり, 端点の数 は $2^{8}=256$ である. そのため, 安定化を考慮すべき 範囲の拡大および計算量の増加によって, 制御系の保 守性を低減するのが難しい. 解析的な手法では, スケ ジューリングパラメータ $p$ が式 (24) のように構造化 され, パラメータの数は 3 個まで低減化でき, 端点の 数が $2^{3}=8$ と少なくすることで, 制御器の設計に用 いる凸包をより小さくできるため, 制御系の保守性を 低減することができる.これを確認するため, シミュ レーション結果を図 5,6 に示す. 図 5 は数值的手法を, 図 6 は 3.2 節に述べた解析的手法を用いた結果である. オイラー角度の初期値は

$$
x=\left[\begin{array}{lll}
\phi_{1} & \phi_{2} & \phi_{3}
\end{array}\right]^{T}=\left[\begin{array}{lll}
0.1 & -0.05 & 0.05
\end{array}\right]^{T}
$$

とした.

この結果より, どちらの手法においても安定に衛星 を伸展できることがわかるが, 解析的な手法を用いた 方が, 収束時間の短縮に効果的なことがわかる. また 数値的な手法では端点が多いため, 計算に要する時間 は增大し, 制御則の実装上, 実用的ではない. 解析的な 手法では端点の数が少なくなるので, 計算時間が大幅 に縮められる.ここでは $b_{1}$ 軸方向の伸展のみを示し たが, $b_{2}, b_{3}$ 軸方向へ伸展させる場合でも, 同様の結果 が得られる.

\section{2 数值例 2}

次にモデル誤差がある場合の $b_{1}$ 軸へ伸展させるシ 

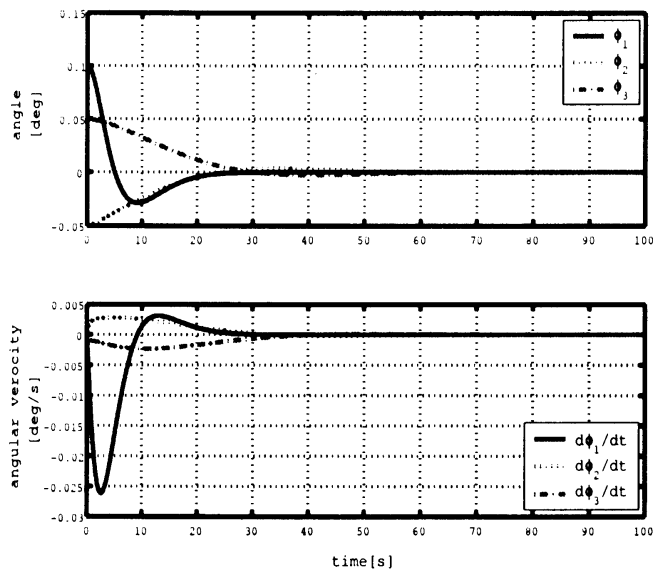

Fig 5 Simulation results extension in the direction of $b_{1}$ axis
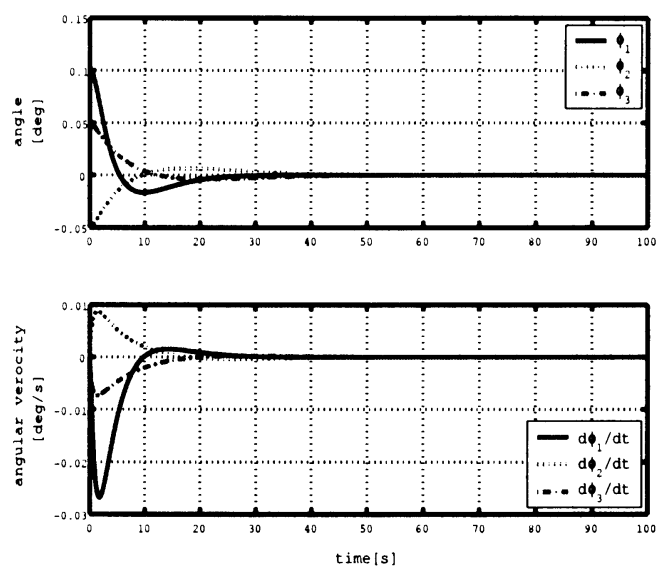

Fig 6 Simulation results extension in the direction of $b_{1}$ axis

ミュレーションを行う．観測された伸展長さ $l$ の時間 履歴を式 (37) と同じように設定し, 観測誤差を

$$
|\Delta l| \leq 0.1 l, \quad\left|\Delta l_{v}\right| \leq 0.1 l_{v}
$$

と仮定する. 伸展方向及び初期値をさきほどと同じよ うに設計した場合，モデル誤差を考慮していない 3.2 節 の方法では図 7 が, モデル誤差を考慮して定数スケー リングにより最適化した 3.3 節の方法では図 8 の結果 がそれぞれ得られた。

この結果より, 図 7 では伸展長さ $l$ と伸展速度 $l_{v}$ の 観測誤差を含むスケジューリングパラメータ $p$ を用い て, 凸結合された制御器では, 図 6 に比べて, 収束時
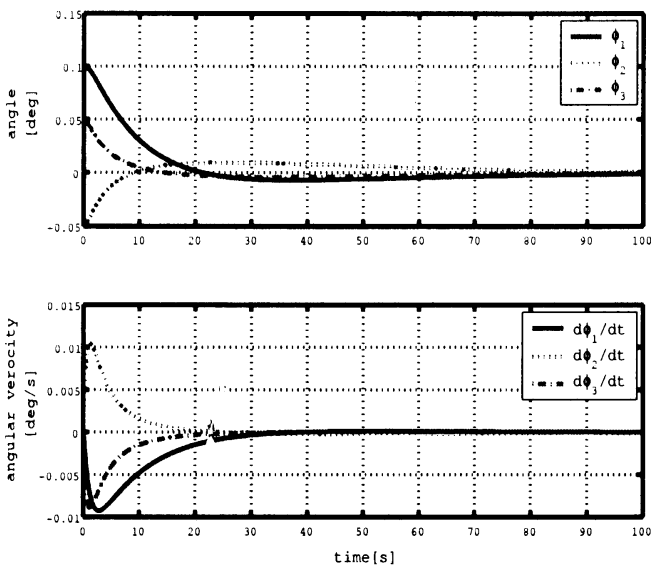

Fig 7 Simulation results extension in the direction of $b_{1}$ axis with the model error
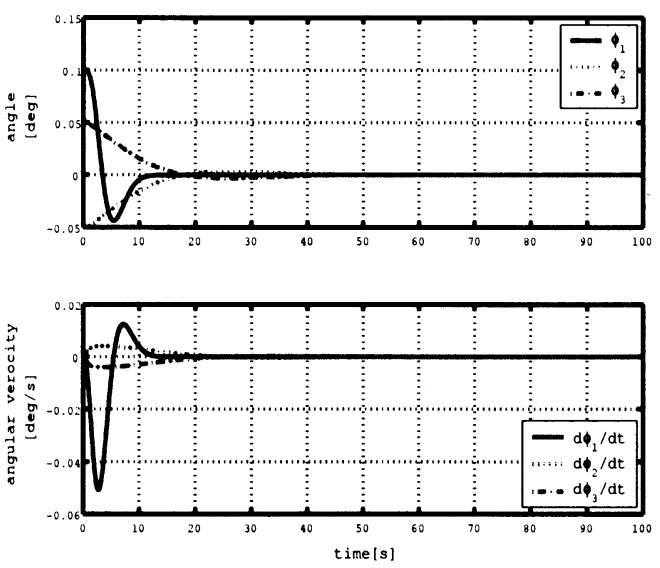

Fig 8 Simulation results extension in the direction of $b_{1}$ axis with the model error

間が長くなり, 制御性能が低下していることがわかる. この数値例では安定な応答を示しているが, 原理的に は安定性も保証されてはいない. 他方, 本稿が提案し た定数スケーリング $H_{\infty}$ 制御とゲインスケジューリン グ制御を併用した図 8 の方は $p$ の誤差をモデル誤差と して扱っているため, 例え観測誤差があった場合でも, ロバスト安定性が保証され, 図 7 に比べて、収束時間 が短く, ロバスト性能も保証されていることがわかる. 


\section{5. 結言}

軌道上で伸展する衛星の運動方程式は伸展しない衛 星の運動方程式とは異なり, 慣性モーメントの時間変 化の項が新たに現われる.この運動方程式は時変シス テムとなり, 伸展しない場合の重力傾度安定化条件は 成り立たない，そこで新たなパラメータを構造化する ことによって, そのシステムを LPV システムに変換 し, ゲインスケジューリング制御法を用いて, 安定に 衛星を伸展できることをシミュレーションによって示 した. また, 衛星にモデル誤差がある場合には定数ス ケーリング行列を用いたロバストゲインスケジューリ ング制御系を設計できることを示した. 本論文では宇 宙構造物を簡単な円柱モデルとしたが, 円盤や長方形 など, その慣性モーメントが解析的に求められる場合 あるいはそのような理想的な形状に近似できる場合に は同様の設計法が適用できる. 実際には, 宇宙構造物 は伸展によって柔軟構造物となる. 弾性振動を考慮し た制御系の設計法が今後の課題である.

\section{文献}

(1) Hughes P.C., Spacecraft Attitude Dynamics, John Wiley and Sons, (1986)

(2) 岡野 竜太郎, 木田 隆, 伸展する宇宙構造物の安定性と 安定化, “計測自動制御学会論文集”, 38 巻, 3 号, (2002), pp.284-292

(3) 木田 隆, スペースクラフトの制御, コロナ社 (1999)

(4) L.Xie, M.Fu and C.E.de Souza, $H_{\infty}$ Control and Quadratic Stabilization of Systems with Parameter Uncertainty Via Output Feedback, IEEE Tr. Automat. Contr. Vol.37, No.8 (1992), pp.1253-1256

(5) P.Apkarian, P.Gahinet and G.Becker, Self-Scheduled $H_{\infty}$ Control of Linear Parameter-Varying Systems, Automatica Vol.31,No.9 (1995), pp.1254-1261

(6) P.Gahinet, A.Nemirovski, A.J.Laub and M.Chilali, LMI Control Toolbox, The Math Works Inc. (1996)

(7) K.Zhou, J.C.Doyle, K.Glover, Robust and Optimal Control, Prentice Hall, (1995) 